\title{
Belgeo
}

Revue belge de géographie

$4 \mid 2019$

Les politiques de mobilité urbaine en Europe après la crise : adaptations et innovations

\section{Citizens with limited autonomy: the forgotten of mobility policies. Lima as an example}

Citoyens à autonomie limitée: les oubliés des politiques de mobilité. Lima à titre d'exemple

Félix Cabrera and Àngel Cebollada

\section{OpenEdition}

\section{Journals}

Electronic version

URL: http://journals.openedition.org/belgeo/36495

DOI: $10.4000 /$ belgeo.36495

ISSN: 2294-9135

\section{Publisher:}

National Committee of Geography of Belgium, Société Royale Belge de Géographie

\section{Electronic reference}

Félix Cabrera and Àngel Cebollada, «Citizens with limited autonomy: the forgotten of mobility policies. Lima as an example », Belgeo [Online], 4 | 2019, Online since 09 February 2020, connection on 19 July 2020. URL : http://journals.openedition.org/belgeo/36495; DOI : https://doi.org/10.4000/belgeo. 36495

This text was automatically generated on 19 July 2020.

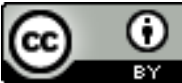

Belgeo est mis à disposition selon les termes de la licence Creative Commons Attribution 4.0 International. 


\section{Citizens with limited autonomy: the forgotten of mobility policies. Lima as an example}

Citoyens à autonomie limitée: les oubliés des politiques de mobilité. Lima à titre d'exemple

Félix Cabrera and Àngel Cebollada

\section{Introduction}

1 The socio-economic and territorial changes that cities have experienced throughout the last century have determined the conceptual and methodological evolution of mobility, and have established all types of pedestrians as a subject of study (MirallesGuasch, Cebollada, 2009). In this article, three phases are identified in the evolution of mobility during the last hundred years (circulatory, multimodal and organic mobility). Each phase can be differentiated by variations in three factors: the determining concepts, the subject of study and the role of public space.

2 In today's city, access to goods and services, and the possibility of travelling autonomously are considered as a right for all citizens (Borja, 2013). Also, territorial policies increasingly include strategies such as compactness, polycentrism and the recovery of public space, in order to create sustainable and equitable cities (Herce, 2013). However, despite these good intentions in cities in developing countries, like Lima, certain social groups, such as citizens with limited autonomy (children, older adults and people with disabilities), still face various difficulties in moving around the city (INEI, 2014).

3 This study analyses people with limited autonomy in the city of Lima, Peru, in order to obtain, from their own testimony, information about their experiences in the urban environment and barriers they face when moving around the city; such information is necessary to improve mobility policies. It should be noted that the different groups are 
examined simultaneously, because there is no single citizen model with homogeneous capacities and needs. The article is organised in five parts. First, the evolution of mobility over the last century and information about citizens with limited autonomy are presented. Second, the area of study is developed. Third, the methodology used in the investigation is explained. Next, the results obtained and discussion are presented, and finally the main research findings are summarised.

\section{Theoretical framework}

Mobility is a cultural, complex and multidimensional phenomenon, which has been analysed from the perspective of different disciplines and in the context of each city (AAG, 2002). However, despite their particularities, cities around the world have followed common stages of evolution due to three factors: change in the territorial economic model, introduction of the sustainability paradigm and inclusion of a concern for the social structure (Miralles-Guasch, Cebollada 2009; Herce, 2009). Based on this approach, to understanding mobility the stages of its evolution are presented below.

\section{Stage 1: Circulatory mobility}

5 At the beginning of the $20^{\text {th }}$ century, cities were overcrowded and faced serious health problems (Gehl, Svarre, 2013). Given this situation, proposals for a functional, specialised and dispersed city emerged, dependent on the automobile for its interconnection (Le Corbusier, 1927; Buchanan, 1964). Subsequently, the urban environment was designed to allow for motorised trips (Clark et al., 2003), meet the travel demand and provide efficient freight transport (Muñoz, 2008). This "circulatory mobility" was associated exclusively with daily, repetitive and obligatory trips that connected the residence to the workplace.

During this stage, pedestrians were considered obstacles to the car and were inadequately represented in research (Middleton, 2009), considered as if they were vehicles (TRB, 2000), gases or fluids (Helbing, Molnar, 1995). Even if this type of city now seems extinct to some policy makers, it is still considered valid for citizens in developing countries such as Mexico (Rojo, 2018) and Peru (Dextre, Avellaneda, 2014).

\section{Stage 2: Multimodal mobility}

7 In the second half of the $20^{\text {th }}$ century, infrastructure networks and automotive fleets increased considerably (Sagaris, 2003), which generated a series of externalities (European Commission, 2004). At the same time, the oil crisis and the debate on environmental problems began (Lemkow, 2002). As a result, multimodal mobility emerged as a concept, with an emphasis on public transport (Clifton et al., 2007), public policies, (Bajada et al., 2016), and non-motorised modes (Sanz, 2005).

During this stage, the pedestrian was represented only by the adult male and the public space was shared by motor vehicles, pedestrians and cyclists through the Radburn principle (Southworth, Ben-Joseph, 1997). Despite the reorganisation of public space, its main function continued to be to facilitate travel; therefore the possibility of social interaction was forgotten (Gehl, Svarre, 2013). 


\section{Stage 3: Organic mobility and the appearance of citizens with limited autonomy}

In this stage new proposals for territorial sustainability arose, such as accessibility (Sanz, 1997), which seeks to encourage proximity dynamics (Miralles-Guasch, Tulla, 2012) and compactness (OECD, 2012). In the latter, people carry out various activities within their neighbourhoods, with short, or micro, trips of 10 to 15 minutes (MirallesGuasch, Marquet Sarda, 2013).

These trips should be made on foot (Ewing, Cervero, 2010), which requires a quality public space, a variety of services and offers the possibility of unexpected activities during the journey (Lavadinho, 2014). These activities enhance urban life and can encourage walking (Gehl, 2006). A public transportation system is also required to connect the different nuclei of the city and encourage equity (Di Ciommo, Lucas, 2014).

One of the most relevant aspects of this stage of evolution of mobility is that at the beginning of the 21st century the social connotations of mobility policy were clearly highlighted and it was recognised that access to the city and to goods and services is a citizen right (Borja, 2013). This means that pedestrians are now subjects for the study of mobility and excluded groups, like people with limited autonomy (children, older adults and those with disabilities) have been incorporated in the design and analysis of public space (Garcia et al., 2014; Garcia, Monk, 2007). People with limited autonomy should have the same life opportunities as an ordinary person (Gelech, Desjardins, 2010); however, they still face various difficulties in moving around the city. In Lima, some are even forced to remain hidden in their households and cannot exercise their fundamental rights (Cabrera, 2019). This is due to the lack of effective public policies and the construction of car infrastructure as a priority (Dextre, Avellaneda, 2014).

Inclusion of people with limited autonomy into society and the city is a multidimensional phenomenon that depend on several factors like the possibility of making trips autonomously (Lid, 2014). Such trips (as a means to get to their daily and optional destinations) are now considered by decision makers to be a relevant objective and it is thought that they can be achieved through three factors: universal design, maintenance of pedestrian infrastructure and the removal of physical and social barriers (United Nations, 2010; Lid, Solvang, 2015). These factors are commonly determined by professionals' perception or expert panels (Ewing, Clemente, 2013).

However, to develop or improve public policies, it is also necessary to empower people with limited autonomy and obtain information from their testimony about their experiences in the urban environment and individual requirements to move around the city (Sherlaw, Hudebine, 2015; Mazurik et al., 2014; Lid, Solvang, 2015). Additionally, it would be advisable to perform a multi-citizen analysis to better understand the relationships of people with their environment in terms of their functional diversity (Hammond, Musselwhite, 2013). All aspects mentioned above determine the guidelines of this research, which focuses on people with limited autonomy.

\section{Area of study}

14 Lima is a city of $9,485,405$ inhabitants (INEI, 2018). It can be placed on the first stage of mobility evolution due to three characteristics: the construction of car infrastructure 
as a priority, the lack of an integrated public transport system (although there is a train line and a BRT line, which are not connected) and the inappropriate design of the city which does not take into consideration the needs of pedestrians (Transitemos, 2014). With respect to its travel pattern, $75 \%$ of them are made by public transport, $11 \%$ by owned car and 12\%, walking (Lima Como Vamos, 2019a).

The geographic sectors of Lima are not homogeneous, with differing economic and social development indexes (INEI, 2018). The most affected people, from the trip perspective, are those with the lowest incomes located on the city's periphery, as well as those with limited autonomy who live throughout the city and are not rich. In some cases, low income people walk long distances because there is no public transport close to their homes. They are even forced to use strategies to avoid paying for public transport (Avellaneda, 2007). They are, moreover, exposed to excessive travel times. For example, $25 \%$ of the population spend more than 2 hours a day to travel to their destination and $10 \%$ more than three hours (Lima Como Vamos, 2016). Also, in Lima travel conditions for people with limited autonomy are unsafe due to the inadequate design of the infrastructure and driver aggressiveness (Dextre, 2010). In 2018, 534 people died due to traffic accidents in Lima (24 were children) and there were 466 fatal events, cars hit pedestrians in 50\% of them (Lima Como Vamos, 2019a).

People with disabilities comprise $11 \%$ of the population of Lima (INEI, 2018) and constitute a special group within those with limited autonomy, since their trips are also affected by the lack of accessibility, lack of employment, dependence and discrimination (Defensoria del Pueblo, 2006). For example, 60\% cannot travel because there are no accessibility elements, $76.8 \%$ do not work, $40.6 \%$ depend on another person to carry out their activities (INEI, 2014) and 27\% have felt discrimination due to their disability, considering only those who can travel (Lima Como Vamos, 2019b). In the case of the elderly, many cannot travel in the city due to their limited physical condition and low incomes (Cabrera, 2019).

In Peru, the design of cities to include people with limited autonomy has been based on professional perspectives, laws and building regulations to eliminate physical barriers. Therefore, the current research has two objectives: to learn the effectiveness of the measures applied so far and to understand the diverse requirements to allow people with limited autonomy to travel autonomously. All information was collected from the participant's points of view, especially low income and middle class people. This information will make it possible to improve public and mobility policies. Additionally, due to recommendations from other research (previously mentioned) a multi-citizen analysis was performed to better understand the relationships of people with their environment in terms of their functional diversity and physical dilemmas.

\section{Methodology}

In this empirical research project, a qualitative and exploratory approach was applied from a phenomenological framework (Sparkes, Smith, 2014) to understand the experiences and barriers that face people with limited autonomy when they move around Lima. A total of 32 people were considered as case studies: seven children (between 8 and 12 years old), five elderly (between 60 and 93 years old) who travelled alone or with the help of an element such as a walker, cane or wheelchair, six adults with motor disabilities (wheelchairs and crutches), seven with visual disabilities 
(congenital and with residual vision), four with cognitive disabilities (autism, and mild and moderate levels of Down syndrome) and three caregivers (family members and therapist). Additionally, other citizens of both genders and who presented a temporary or permanent disability were included. Participants were recruited after visiting a school, a poor neighbourhood, institutions of people with disability and by applying the snowball technique.

Individual in-depth interviews were conducted, except in the case of children, where a group interview was done. These interviews were characterised by being flexible and dynamic (King, Horrocks, 2010), so in their question guide, topics were considered using a semi-structured format in order to capture, if necessary, aspects that were not originally considered (Valles, 1997).

It was emphasised that the interviews would be anonymous. They lasted between 45 and 65 minutes, except in the case of people with cognitive disabilities and older adults, where the duration was approximately 30 minutes. All interviews were audio recorded, and transcribed later. The analysis process began with the determination of the content units, for which a "free flow" unit was chosen, where what mattered was the meaning and not the number of sentences.

Then, in each interview transcription the meaning of the units was analysed to determine the categories using the techniques of counting, processing (HernándezSampieri et al., 2014) and "constant comparison" (Tracy, 2013). Finally, when category saturation was reached (Neuman, 2009), it was decided that it was not necessary to collect more information; explanations and resulting theory were developed giving rise to the results shown below.

\section{Results and discussion}

This research found that citizens with limited autonomy constitute a heterogeneous group, in which each type of person has its own requirements, some of which even conflict. This corroborates what was found in other studies (Poldma et al., 2014; Los Angeles County, 2011). Also, this research confirms that these citizens show complex realities that, in the case of people with disabilities and older adults, cover psychological, social and physical fields. This agrees with the findings of Brogna (2009). In contrast, in children the use of public space is restricted by social barriers, as was stated by Tonucci (2004).

Developing a schema that encompasses the requirements of all these types of citizens (to move around the city) could be considered a complex task. However, as a result of the information obtained in the interviews, an initial schema is proposed, called: "the cyclic chain of requirements to travel".

\section{The cyclic chain of requirements to travel}

In general terms, the trips of a person with limited autonomy would occur after attainment of a set of requirements, which are continuously interrelated and can follow a cyclical process. Not all citizens have the same requirements. People with disabilities would need to overcome all the components of the chain, while children 
and older adults mainly face social and physical barriers. Figure 1 shows the five elements that make up this chain:

- the personal sphere

- learning trip techniques

- trip autonomy

- physical barriers and

- social barriers

Figure 1. Cyclic chain of requirements to travel.

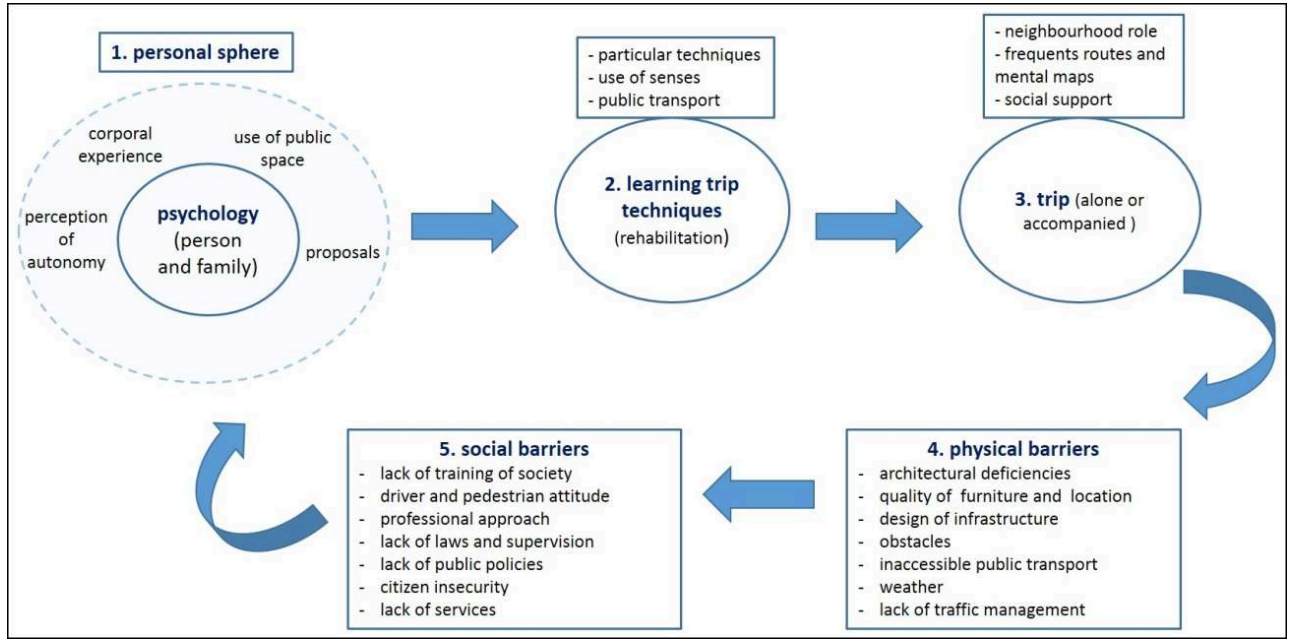

Source: Authors' own elaboration

All chain components interact continuously in a complex way, so some of them have greater relevance within the cyclic process. For all types of citizens interviewed, the fundamental component was the personal sphere; in this our research differs from other studies that emphasise only physical and social barriers (Swaine et al., 2014; Argyropoulos, Kanari, 2015). If the problems within this area cannot be overcome, trips cannot be made, even if infrastructure is adequate, and therefore neither can social interaction. However, in the case of children and older adults (those who walk alone and without help), problems within this area are few. According to our interview results, people are classified into two groups: those with disabilities, and children and the elderly.

\section{Personal sphere of people with disabilities}

As stated earlier, it would not be possible to go out in the city or perform activities if the person with a disability or his/her nuclear family does not have a stable and healthy emotional state. Our interviews indicate that people with disabilities suffer from lack of self-esteem and constant depression, and this is exacerbated in the case of people who acquire a disability, motor or visual, due to an accident or illness after birth. In the latter case, interviews indicated that there is a continuous comparison of previous "normal" experience, with the current one, disabled, and how this is a tremendous barrier that can generate periods of grief, lasting about a year.

While it is true that a person's disability also affects close family members (who see their own daily activities limited), the greatest impact would occur in the case of people 
with cognitive disabilities. According to caregivers, in the same way as indicated by Benevento (2016), parents would face initial dilemmas related to the loss of the "normal child", not born. Additionally caregivers indicated that self-questioning is common, such as "What have I done to deserve this? Why me? What am I going to do with this burden?" Dealing with these situations is complicated and may even cause one of the parents to leave the family. Also caregivers indicated that the mother or the father alone with the child would face a situation of stress and pain that could even lead to pathological situations difficult to overcome. Parents are the first link in a future chain of accessibility and if they do not look with love to their children, then society will not do so either and, therefore, will not be able to initiate any integration process. This also matches what was found by Brogna (2009).

\section{Learning trip techniques for people with disabilities}

28 Once the psychological requirements of people and their families have been fulfilled, the next step is to start rehabilitation or empowerment so that the disabled person can travel alone or with help. Within the groups considered, people who use wheelchairs (suffering degenerative diseases) would not require much preparation (because they are assisted), but would feel strongly integrated with their support elements (such as wheelchairs and crutches) and with their assistants. Interviewees indicated that the wheelchair and the assistant would become extensions of the body, which would determine a body experience. Authors of the present paper call it "motor fusion"; it is of different degrees depending on the level of disability. This body experience was also found by Lid, Solvang (2015).

The situation of people with visual and cognitive disabilities is different. In the case of the former, their rehabilitation process requires assistance to travel to specialised institutions in order to learn the techniques of travel available. The blind, analogously to people using wheelchairs, indicated that they conceive the cane as an extension of the body, allowing them to identify obstacles in the streets and create an individual experience of the city. This is similar to what was found by Bickenbach (2012). However, initially, it was very difficult for them to accept its use. From the perspective of those interviewed who were previously able to see, one of the main reasons for rejection of a cane is that its use is associated with a state of destitution, with the term "disabled" being for them synonymous with "beggar". This rejection of a cane was also found in another study where the cane was a symbol of disability (Shakespeare, 2006). The blind must also go through a complex preparation period to create mental maps of their frequent routes, based on the information they can collect with their other senses such as hearing and smell. This was also indicated by Parkin, Smithies (2012). To do this, they would need to carry out prior inspections accompanied by a family member or friend.

On the other hand, people with cognitive disabilities, specifically those with Down syndrome and with mild brain injury, indicated that they use frequent routes and mental maps to move, constructed from architectural and natural details. This result matches those of another study (Goldsmith, 1996). In these cases, route selection required the help of family members and learning and started in childhood. However, in most such cases, these people travel accompanied, especially if the family has financial resources. Additionally, people with cognitive disabilities indicated, in the 
same way as found by Mitchell et al. (2003), that they can lose spatial orientation and assume unexpected behaviours due to the hypersensitivity of their sensory apparatus. For example, too many lights, sunlight or excessive noise can annoy them, cloud their perceptions or generate a crisis. In the same way, poor signalling, the need to process a lot of information simultaneously, and high pedestrian and vehicular volumes affect their spatial orientation and mobility.

\section{Trip autonomy of people with disabilities} they can begin autonomous travel (according to their own perception of what this means). People with motor disabilities who use wheelchairs are permanently assisted in their movements and adapt their wheelchairs so they can enter taxis and ramps. In contrast, visually impaired people walk alone and depend on a support chain. They request the help of people who are on the streets in at least three places: at a public transport stop, inside buses and on the sidewalks (to gather information and to cross the streets).

On the other hand, people with cognitive disabilities could travel alone within their neighbourhoods. In this situation, the role of neighbours would be fundamental so that the family's perception of insecurity is attenuated and autonomy is encouraged.

\section{Physical barriers faced by people with disabilities}

People with disabilities face a series of physical barriers during travel. The authors grouped the barriers indicated by those interviewed into the following: architectural deficiencies; quality of furniture and location; design and condition of infrastructure; physical obstacles; inaccessible public transport; weather; and inadequate traffic management. These barriers generate different impacts depending on the type of disability.

Architectural deficiencies and the quality and condition of the furniture refer to the barriers that are found within buildings, which would mainly affect people with a motor disability. People interviewed reported the following as barriers associated with the design and condition of infrastructure: the poor condition and design of the pavement and ramps, and a lack of medians at intersections. This is comparable to what was established in Los Angeles County (2011). Similarly, inaccessible public transport would be an impassable barrier for people with motor disabilities, who cannot get into the buses and are forced to travel by taxi. Also, rain and heat can affect the movements of people in wheelchairs, especially when climbing slopes. In the case of a person with a severe disability, the description of the experience mainly involves the inconvenience reported by their assistants. The same result was obtained in another study (Holloway et al., 2010).

Also, interviewees indicated that high obstacles such as open windows affect people with visual impairment, since they cannot be detected by the cane. In addition, the placement of the road and sidewalk at the same level would seriously affect their mobility, since a difference in levels is essential to prevent people with visual disabilities from thinking that the sidewalk is part of the road. This result coincides with the findings of other studies (Los Angeles County, 2011; Lid, Solvang, 2015).

Belgeo, 4 | 2019 

buses, due to the height of the interior. They could also easily lose their balance when the bus moves and would tend to be emotionally affected when vehicles are saturated with people. Similarly, inadequate traffic management, such as traffic lights with phases not distinguished by different sounds, and inadequate regulation of the circulation of heavy vehicles and moto-taxis ${ }^{1}$ affect all groups.

\section{Social barriers faced by people with disabilities}

Regarding social barriers, the lack of training of the public to help people with disabilities, the attitude of pedestrians and drivers, professional approach (by architects and engineers), regulations and poor local government supervision, lack of public policies, insecurity and lack of services were revealed during the interviews.

Lima society is unaware of the characteristics and needs of people with visual disabilities. People interviewed reported that society does not know how to help them when they request support to cross the street, and often insult them. Few people know how to talk with a person with Down syndrome, which prevents communication. Another relevant barrier is the negative attitude of the drivers of private vehicles and public transport workers, who are insulting (mainly to people with cognitive disabilities), do not respect traffic rules and behave aggressively.

Also, eight people interviewed indicated that measures to address motor disability are prioritised in the design of the city, since people with motor disabilities are perceived to have a greater disability and there is the belief that in Peru, motor disabilities are more common than with visual disabilities. This is erroneous, since according to INEI (2018), if one type of disability is considered, in Peru, more people have visual disabilities (48\%) than motor (15\%).

Similarly, interviewees stressed that public institutions have inaccessible buildings and law $\mathrm{N}^{\circ}$ 29973, promulgated by the Peruvian state (Diario Oficial El Peruano, 2012), conflicts with national building regulations (Ministerio de Vivienda, Construcción y Saneamiento, 2016); the latter do not allow for adequate infrastructure. At the same time, they mentioned that local governments do not carry out proper inspection of buildings to determine whether they are accessible. These factors made them feel forgotten by mobility policies.

\section{The repetition of the cycle of requirements of people with disabilities}

Once people with a disability have faced physical and social barriers, they have the possibility of establishing their own perception of what autonomy is, defining the use of public space, perceiving their body experiences and offering solutions. Of course, if the experiences with the different types of barriers are negative, the psychology of the disabled person could be affected and this would inhibit their mobility, which would lead to a new cycle of requirements.

The results indicate that the definition of autonomy varies and depends on the type of disability, whether it was congenital or subsequently acquired, and whether temporary or permanent. Likewise, due to the lack of road safety, people with visual disabilities 
reported perceiving the use of public space not for sedentary activities but for travelling in order to carry out mandatory activities, such as shopping. In addition, being aware of the dangers of the street would consume all their attention. On the other hand, people with motor disabilities, who are assisted, use public space as a place to carry out the most basic social activity: observing other people.

Interviewees offered similar proposals to improve their mobility (improvement of paths, ramps, public transport, speed control, traffic management, inspection and control). Finally, the people interviewed point out that measures applied so far, by the Peruvian state, have not allowed its social integration, and the disabled must be part of improvement projects or at least should participate in their evaluation.

\section{Requirements of children and older adults}

Children and older adults need to meet only some of the requirements of the cyclic chain shown in Figure 1. In the case of children, social barriers (such as citizen insecurity and lack of road safety) determine parents' perception of security and therefore the possibility of children moving alone, at least within their neighbourhoods (Cook et al., 2015). In this research, a special situation was detected, where children from poor families travel alone, since parents work almost all day and do not have the possibility of accompanying them. However, the girls in these families indicated they walk quickly in a group with friends due to insecurity and violence against them. This would reflect how since childhood girls and boys have a different pattern of behaviour in the public space.

Older adults need almost all requirements to be met, except for learning mobility techniques. Due to their diminished physical condition, architectural and physical barriers seriously restrict their travel, as was indicated by PROMISING (2011). For example, there are areas with special topographic characteristics (steep and uneven slopes), pavement with holes and smooth or rough surfaces, and open maintenance holes without covers. These problems are closely related to the physical characteristics of many older adults, who walk slowly, and cannot easily lift their feet or climb stairs. This matches what was found by Karekla, Tyler (2016).

Similarly, social barriers, such as citizen insecurity and lack of road safety (driver behaviour), present restrictions on their movements. If physical and social barriers cause accidents and physical injury to older adults, this would also trigger psychological damage that would lead them to reassess four aspects: their perception of autonomy, the need to travel accompanied, use of a support element and whether to remain at home. Interviewees underlined that fears of falling and breaking bones is common within this group of people, as was indicated in another study (De Jong, 2014). This creates a vicious circle in which the majority decides not to leave home and consequently relinquishes the possibility of walking, even if this is the best physical exercise they can perform to maintain cognitive functions (Borst et al., 2009).

\section{Conclusions}

In the third stage of mobility evolution, all pedestrians are considered as pertinent to the study of mobility. Therefore excluded groups, like people with limited autonomy, are incorporated in the design and analysis of public space. Unfortunately, Lima 
appears to be in the first stage of evolution, in which these people still face various difficulties in moving around the city or remain hidden in their households and cannot exercise their fundamental rights.

Additionally, this research shows that each citizen with limited autonomy constitutes a particular world due to human diversity and biopsychosocial construct. Therefore, they each have different characteristics and specific requirements for travel. The simultaneous analysis of the cases showed that in order for trips to occur, the requirements of a "cyclic chain" with up to five components must be met: the personal sphere, the learning of trip techniques, trip autonomy, physical barriers and social barriers. People with disabilities would need to overcome all five components, while for children social barriers comprise the principal component, and for the elderly, it is mainly the physical barriers (although the psychological ones appear as well, due to the fear that they will fall and fracture the bones).

Findings of this study also indicate that physical barriers in Lima are similar to those found in other cities, possibly due to common human body characteristics. It is often though that trips of people with disabilities will occur as long as physical barriers are removed. However, this research has identified the importance of the personal field as the first element to be considered within public policies, which seek to include people with disabilities in the public realm. Moreover, this aspect is not only for the individual, but also for their close relatives, such as parents and siblings.

50 For example, people cannot go out in the city or perform activities, if they or their nuclear family do not have a stable and healthy emotional state. In addition, in all the cases analysed, the greatest impact was suffered by parents of children with cognitive disabilities, as they faced the initial dilemma of the loss of the "normal child" they expected to be born. Another case is of people who acquired the disability due to an accident or illness after birth. In this situation, the continuous comparison of the previous experience, with the current one, disabled, was found by many of those interviewed to be a tremendous barrier that would even generate periods of suffering. This leads us to ask the following: is it probably less traumatic to be born with a disability than to acquire it later? Since in this second case, the status of a "normal" person would be lost.

51 Furthermore, interviewees indicated that measures applied so far, by the Peruvian state, have not allowed its social integration and the disabled should be involved in the design and evaluation of infrastructure projects. Also, psychological aspects are strongly related to social barriers. The interviewed indicated that, in Lima, the population still looks at disability with eyes of indifference and as a curse that only affects the helpless and unfortunate. So, society is not aware that disability is part of everyone's life cycle, which can temporarily affect any of us (e.g. after an accident) and will inevitably be part of old age. That is, disability is a human characteristic and is the representation of our functional diversity. Also eight interviewees indicated that those with motor disability enjoy certain privileges in the design of the city of Lima (due to their greater perceived disability). This leads us to ask the following: is there a hierarchy among people with limited autonomy?

In view of the results obtained, the need to have policies that integrate people with limited autonomy to the society has been confirmed. But mobility policies should focus not only on the removal of physical barriers; strengthening the public health system is essential so that people can overcome their psychological barriers first. It is necessary 
to work with their biopsychosocial sphere and analyse the principles of universal design, due to the physical dilemmas (people with limited autonomy have different requirements to travel). This leads us to ask ourselves the following: could a public space be designed that serves all types of people? Or should as many individuals as possible be favoured, which would inevitably marginalise certain groups. Finally, mobility policies should also consider plans that modify the "model" of a person that is currently used in Lima society. In other words, the idea that a person is only someone who is able to reason, exchange opinions and is fully physically functional must be changed.

\section{BIBLIOGRAPHY}

AAG (2002), Trends in the geography of mobility, USA, Association of American Geographs, $98^{\text {th }}$ Annual meeting.

ARGYROPOULOS V., KANARI C. (2015), "Re-imagining the museum through 'touch': reflections of individuals with visual disability on their experience of museum-visiting in Greece", ALTER, 9, pp. 130-143.

AVELLANEDA P. (2007), Movilidad, pobreza y exclusión social. Un estudio de caso en la ciudad de Lima, Tesis de doctorado, Bellaterra, Universidad autónoma de Barcelona.

BAJADA T., MIFSUD D. \& Di CIOMMO F. (2016), “Accessibility as an indicator of transport equity. The case of public transport infrastructure in Malta, and its impact on the elderly", Xjenza, 4, 1, pp. 72-81.

BENEVENTO, D. (2016), Discapacidad. Un Nuevo desafío familiar, Buenos Aires, editorial Bonum. BICKENBACH J. (2012), Ethics, law and policy, Thousand Oaks, Sage.

BORJA J. (2013), Revolución urbana y derechos ciudadanos, Madrid, Alianza editorial.

BORST H., SANNE I., GRAHAM J., DONGEN J. \& BAKKER I. (2009), "Influence of environmental street characteristics on walking route choice of elderly people", Journal of Environmental Psychology, 29, 4, pp. 477-484.

BROGNA P. (2009), Visiones y revisiones de la discapacidad, México, Fondo de cultura económica. BUCHANAN C. (1963), Traffic in towns, Harmondsworth, Penguin Books.

CABRERA, F. (2019), Movilidad, espacio público y ciudadanos sin autonomía: el caso de Lima, Tesis de doctorado, Bellaterra, Universidad autónoma de Barcelona.

CLARK W., HUANGB Y. \& WITHERSC S. (2003), "Does commuting distance matter? Commuting tolerance and residential change”, Regional Science and Urban Economics, 33, pp. 199-221.

CLIFTON K. J., LIVI SMITH A.D. \& RODRIGUEZ D. (2007), "The development and testing of an audit for the pedestrian environment", Landscape and Urban Planning, 80, pp. 95-110. 
COOK A., WHITZMAN C. \& TRANTER P. (2015), "Is citizen kid an independent kid? The relationship between children's independent mobility and active citizenship", Journal of Urban Design, 20, 4, pp. 526-544.

DE JONG M. (2014), How to move around comfortably and safely with a reduced Ability to Walk, See, Hear, Feel or Process, in WEIDMANN U., KIRSCH U. \& SCHRECKENBERG M. (eds.), Delft, Pedestrian and Evacuation Dynamics 2012, vol. 1.

DEFENSORIA DEL PUEBLO (2006), Barreras físicas que afectan a todos. Supervisión de las condiciones de accesibilidad de palacios municipales, Lima, Perú.

DEXTRE J.C., AVELLANEDA P. (2014), Movilidad en zonas urbanas, Lima, Fondo editorial de la Pontificia Universidad Católica del Perú.

DEXTRE J.C. (2010), Seguridad vial: la necesidad de un nuevo marco teórico, Tesina en Departamento de Geografía, Bellaterra, Universidad Autónoma de Barcelona.

DIARIO OFICIAL EL PERUANO (2012), Ley 29973, ley general de la persona con discapacidad, Lima, Perú. DI CIOMMO F., LUCAS K. (2014),. "Evaluating the equity effects of road-pricing in the European urban context - the Madrid metropolitan area”, Applied Geography, 54, pp. 74-82.

EUROPEAN COMMISSION (2004), Reclaiming city streets for people, chaos or quality of life, Brussels.

EWING R., CERVERO R. (2010), "Travel and the built environment”, Journal of the American Planning Association, 76, 3, pp. 265-294.

EWING R., CLEMENTE O. (2013), Measuring urban design, Washington DC, Island Press.

GARCÍA RAMON M., ORTIZ A. \& PRATS M. (2014), Espacios públicos, género y diversidad: geografías para unas ciudades inclusivas, Barcelona, Icaria editorial.

GARCIA RAMON M., MONK J. (2007), “Gender and geography: world views and practices”, Belgeo, 3, pp. 247-260.

GELECH J., DESJARDINS M. (2010), “Se déplacer entre les marges et le centre: stratégies de reconstruction suite à un traumatisme craniocérébral”, Frontières, 22, 1-2, pp. 69-77.

GHEL J. (2006), La humanización del espacio urbano. La vida social entre los edificios, Barcelona, Editorial Reverté.

GHEL J., SVARRE B. (2013), How to study public life, Washington DC, Island Press.

GOLDSMITH M. (1996), Hearing the voice of people with dementia: opportunities and obstacles, London, Jessica Kingsley.

HAMMOND V., MUSSELWHITE C. (2013), “The Attitudes, perceptions and concerns of pedestrians and vulnerable road users to shared space: A case study from the UK", Journal of Urban Design, 18, 1, pp. 78-97.

HELBING D., MOLNAR P. (1995), “Social force model for pedestrian dynamics”, Physical Review E, 51,5, pp. 4282-4286.

HERCE M. (2009), Sobre la movilidad en la ciudad. Propuestas para recuperar un derecho ciudadano, Barcelona, editorial Reverté.

HERCE M. (2013), El negocio del territorio. Evolución y perspectivas de la ciudad moderna, Barcelona, Alianza editorial.

HERNADEZ-SAMPIERI R., FERNANDEZ C. \& BAPTISTA M. (2014), Metodología de la investigación, México, Mc Graw Hill Education. 
HOLLOWAY C., SUZUKI T., UCHIYAMA H. \& TYLER N. (2010), Application of the Capability Model to Assess Crossfall Gradient Requeriments for Attendanst Pushing Wheelchairs, Hong Kong, TRANSED 2010. INEI (2018), Perú: Perfil sociodemográfico: informe nacional, Lima, Instituto Nacional de Estadística e Informática.

INEI (2014), Primera Encuesta Nacional Especializada Sobre Discapacidad 2012, Lima, Instituto Nacional de Estadística e Informática.

KAREKLA X., TYLER, N. (2016), Gait and balance of moving bus passengers, Lisbon, TRANSED 2016.

KING N., HORROCKS C. (2010), Interviews in qualitative research, USA, Thousand Oaks.

LAVADINHO S. (2014), "Dinámicas de proximidad en la ciudad: ideas para la transformación urbana", Ciudades, 17, 1, pp. 21-39.

LE CORBUSIER (1927), Towards a new architecture, London, The Architectural Press.

LEMKOW L. (2002), Sociología ambiental: pensamiento socioambiental y ecología social del riesgo, Barcelona, Icaris.

LID I., SOLVANG P. (2015), "(Dis)ability and the experience of accessibility in the urban environment", ALTER, 10, pp. 181-194.

LID I. (2014), “Universal design and disability: an interdisciplinary perspective”, Disability and Rehabilitation, 36, 16, pp. 1344-1349.

LIMA COMO VAMOS (2019a), ¿Cómo vamos en Lima y Callao? Noveno informe de indicadores sobre calidad de vida, Lima, Perú.

LIMA COMO VAMOS (2019b), Lima y Callao según sus ciudadanos. Décimo informe urbano de percepción sobre calidad de vida en la ciudad, Lima, Perú.

LIMA COMO VAMOS (2016), Evaluando la gestión en Lima. Sexto informe de resultados sobre calidad de vida, Lima, Perú.

LOS ANGELES COUNTY (2011), Model design manual for living streets, USA, Los Angeles County.

MAZURIK K., DESJARDINS M., GROSBOIS É., POLDMA T. \& GELECH J. (2014), “Individual stakes and collective ideology in tension: looking at physical and spatial obstacles from an experiential perspective", ALTER, 8, pp. 194-205.

MIDDLETON J. (2009), “Stepping in time: walking, time and space in the city”, Environment and Planning A, 41, pp. 1943-1961.

MINISTERIO DE VIVIENDA, CONSTRUCCION Y SANEAMIENTO (2016), Reglamento nacional de edificaciones, Lima, Perú.

MIRALLES-GUASCH C., MARQUET SARDÁ O. (2013), "Dinámicas de proximidad en ciudades multifuncionales", CyTET XLV, 177, pp. 503-512.

MIRALLES-GUASCH C., TULLA A. (2012), “La región metropolitana de Barcelona. Dinámicas territoriales recientes”, Boletín de la Asociación de Geógrafos Españoles, 58, pp. 299-318.

MITCHELL. L., BURTON E. \& RAMAN S. (2003), "Making the outside world dementia-friendly: design issues and considerations", Environment and Planning B: Planning and Design, 30, pp. 605-632. MUÑOZ F. (2008), Urbanalización. Paisajes comunes, lugares globales, Barcelona, Editorial Gustavo Gili.

MIRALLES-GUASCH C., CEBOLLADA A. (2009), "Movilidad cotidiana y sostenibilidad, una interpretación desde la geografía humana". Boletín de la A.G.E., 50, pp. 193-216. 
NEUMAN W.L. ( $7^{\text {th }}$ ed., 2009), Social research methods: qualitative and quantitative approaches, Upper Saddle River, NJ, Pearson.

OECD (2012), Compact city policies: a comparative assessment. OECD Green Growth Studies, Paris, OECD Publishing.

PARKIN J., SMITHIES N. (2012), “Accounting for the needs of blind and visually impaired people in public realm design”, Journal of Urban Design, 17, 1, pp. 135-149.

POLDMA T., LABBÉ D., BERTIN S., GROSBOIS É., BARILE M., MAZURIK K., DESJARDINS M., HERNANE H. \& ARTIS G. (2014), “Understanding people's needs in a commercial public space: About accessibility and lived experience in social settings”, ALTER, 8, pp. 206-216.

PROMISING (2011), Measures for pedestrians safety and mobility problems. Final Report of workpackage 1 of the European research project PROMISING, Athens, National Technical University of Athens.

SAGARIS L. (2003), Muévete por tu ciudad. Una propuesta ciudadana de transporte con equidad, Santiago, LOM Ediciones.

SANZ A. (2005), El viaje de las palabras. El derecho a la movilidad, Valladolid, Escuela Técnica Superior de Arquitectura de Valladolid, pp. 87-93.

SANZ A. (1997), Movilidad y accesibilidad: un escollo para la sostenibilidad urbana, http:// habitat.aq.upm.es/cs/p3/a013.html [Retrieved March 2007].

SHAKESPEARE T. (2006), Disability rights and wrongs, London, Routledge.

SHERLAW W., HUDEBINE H. (2015), “The United Nations convention on the rights of person with disabilities: opportunities and tensions within the social inclusion and participation of persons with disabilities", ALTER, 9, pp. 9-21.

SOUTHWORTH M., BEN-JOSEPH E. (1997), Streets and the shaping of Towns and cities, Washington DC, Island Press.

SPARKES A., SMITH B. (2014), Qualitative research methods in sport, exercise and health: From process to product, New York, Routledge.

SWAINE B., LABBÉ D., POLDMA T., BARILE M., FICHTEN C., HAVEL A., KEHAYIA E., MAZER B., MCKINLEY P. \& ROCHETTE A. (2014), "Exploring the facilitators and barriers to shopping mall use by persons with disabilities and strategies for improvements: perspectives from persons with disabilities, rehabilitation professionals and shopkeepers", ALTER, 8, pp. 217-229.

ROJO J.C. (2018), El deterioro del espacio público y su impacto en las áreas destinadas a la socialización y al desarrollo de la accesibilidad en las ciudades medias mexicanas. Caso Culiacán, Sinaloa, Tesis de doctorado, Bellaterra, Universidad Autónoma de Barcelona.

TONUCCI F. ( $3^{\text {ra }}$ ed., 2004), La ciudad de los niños. Un nuevo modo de pensar la ciudad, Buenos Aires, Editorial Lozada S.A.

TRACY S.T. (2013), Qualitative research methods: collecting evidence, crafting analysis, communicating impact, USA, Wiley-Blackwell.

TRANSITEMOS (2014), Hacia una Ciudad para las Personas, Lima, Perú.

TRB ( $4^{\text {th }}$ ed., 2000), Highway capacity manual 2000, Washington DC, Transportation Research Board.

UNITED NATIONS (2010), Monitoring the convention on the rights of persons with disabilities, guidance for human rights monitors professional training series, 17, New York and Geneva, Office of the High Commissioner for Human Rights. 
VALLES M.S. (1997), Técnicas cualitativas de investigación social: Reflexión metodológica y práctica profesional, Madrid, Colegio de Sociología.

\section{NOTES}

1. Moto-taxi is a Peruvian means of transport that can be defined as a three-wheeled motorcycle with a roof that is used for short distances in exchange for payment, in the same way as a taxi.

\section{ABSTRACTS}

New mobility policies focus on the right to a sustainable, equitable and accessible city. Thus, urban environments are gradually being transformed to become more inclusive, favouring journeys on foot, by bicycle and public transport, and achieving a wider ownership of public space, while limiting the use of private vehicles. However, no single model, with homogeneous capacities and needs, represents a human being; in fact, there is a large number of heterogeneities. Habitually, cities have been built for a single individual: male, middle-aged and with full physical and mental faculties. This article presents the results of a case study in the city of Lima, Peru. Research is based on interviews to understand the barriers that groups of citizens with limited autonomy (older adults, children, the motor disabled, the visually impaired and the cognitively disabled) face when they move around the city. The cyclical chain of requirements to travel is identified. The article concludes with a call for public mobility policies to integrate the biopsychosocial sphere to encourage autonomous journeys by the entire citizenry.

Les nouvelles politiques de mobilité se concentrent sur le droit à une ville durable, équitable et accessible. Ainsi, les environnements urbains se transforment progressivement pour devenir plus inclusifs, favorisant les déplacements à pied, à vélo et en transports en commun et élargissant la propriété de l'espace public, tout en limitant l'utilisation des véhicules privés. Cependant, il n'y a pas de modèle unique d'un être humain, avec des capacités et des besoins homogènes; en fait, il existe un grand nombre d'hétérogénéités. Habituellement, les villes ont été construites pour un seul individu: homme, d'âge moyen et avec de pleines facultés physiques et mentales. Cet article présente les résultats d'une étude de cas dans la ville de Lima, au Pérou. La recherche est basée sur des entretiens pour comprendre les obstacles auxquels sont confrontés les groupes de citoyens à autonomie limitée (personnes âgées, enfants, handicapés moteurs, malvoyants et cognitifs) lorsqu'ils se déplacent en ville. La chaîne cyclique des exigences de déplacement est identifiée. L'article se termine par un appel à des politiques de mobilité publique pour intégrer la sphère biopsychosociale afin d'encourager les déplacements autonomes de l'ensemble des citoyens.

\section{INDEX}

Mots-clés: mobilité, autonomie limitée, politiques publiques, handicap, Lima, Pérou

Keywords: mobility, limited autonomy, public policies, disability, Lima, Peru 
AUTHORS

FÉLIX CABRERA

Pontificia Universidad Católica del Perú, cabrera.fi@pucp.edu.pe

ÀNGEL CEBOLLADA

Universitat Autònoma de Barcelona, Angel.Cebollada@uab.cat 